• e ISSN-0976-6855 | Visit us : www.researchjournal.co.in

\title{
Integrated disease management of anthracnose of cowpea caused by Colletotrichum lindemuthianum
}

\author{
M.R. DABBAS*, SHRAWAN KUMAR, PRITI TIWARI AND S.D.DUTTA \\ Vegetable Section, C.S. Azad University of Agriculture and Technology, KANPUR (U.P.) INDIA
}

\section{ARITCLE INFO}

Received : 25.06 .2015

Revised : 03.08 .2015

Accepted : 18.08 .2015

\section{KEY WORDS :}

Thiophanate methyl, Difenaconazole, Pseudomonas fluroscens, Trichoderma viride.

*Corresponding author:

Email:drmrdabbas@gmail.com

\begin{abstract}
Cowpea (Vigna unguiculata L.) is the most important legume and vegetable crop grown in India. Most of the promising cowpea cultivars are under a great threat for profitable cultivation due to the attack of several abiotic and biotic factors viz., Fungi, bacteria, virus and nematodes. The major losses of cowpea are covered by fungi, in which anthracnose caused by Colletotrichum lindemuthianum is more important. The experiment on integrated disease management of cowpea anthracnose disease under field conditions with twelve treatments and three replications using fungicides and bio-agent formulations was conducted during 2013-14 and 2014-15. The mean of analysis of two years data revealed that the three foliar sprays of Thiophenate methyl $(0.1 \%)$ at 10 days interval from initiation of the disease gave average minimum disease intensity (10.63\%) and maximum edible pod yield (11.34 q/ha). This was followed by foliar sprays of Difenaconazole $(0.06 \%)$ which gave average 16.94 per cent disease intensity and pod yield $9.99 \mathrm{q} / \mathrm{ha}$. From the table it is cleared that the fungicides belonging to Trizole groups are more effective.

How to view point the article : Dabbas, M.R., Kumar, Shrawan, Tiwari, Priti and Dutta, S.D. (2015). Integrated disease management of anthracnose of cowpea caused by Colletotrichum lindemuthianum. Internat. J. Plant Protec., 8(2) : 261-264.
\end{abstract}

